\title{
EKSPLORASI DAN KARAKTERISASI CENDAWAN TANAH PADA RIZOSFER SAWI
}

\author{
Eko Hary Pudjiwati ${ }^{1}$, Nur Faradila Sari ${ }^{2}$, Jamaludin Jamaludin ${ }^{3}$ \\ 1,2,3 Fakultas Pertanian, Universitas Borneo Tarakan, Jl. Amal Lama No. 1 Tarakan \\ e-mail: inok3959@gmail.com
}

Receive: 18 September 2019

Accepted: 3 Oktober 2019

\begin{abstract}
Soil fungis are one of the soil microbes that can be beneficial or detrimental to plants, so they play an important role in agriculture. This study aims to determine the abundance and characterization of soil fungi in the rhizosphere of mustard greens. Isolation and identification of soil fungus was carried out in the Pest and Disease Laboratory of the Faculty of Agriculture, University of Borneo Tarakan. The fungus was characterized macroscopically and microscopically, and the pathogenicity test, phosphate dissolution activity test, proteolytic activity test and chitin hydrolysis test were carried out. The results of the study obtained 34 fungus colonies. Based on the phenotypic characteristics there were 9 fungi isolates with different characteristics, 4 isolates from 9 isolates were non-pathogenic. In non-pathogenic fungi isolates, 2 genera were obtained, namely genus Phialophora sp. and Paecilomyces sp. There are non-pathogenic fungus isolates that have proteolytic activity and chitin hydrolysis so that it has the potential as a biological fertilizer and biological agent
\end{abstract}

Keywords: Soil fungis, rhizosphere, characterization

\begin{abstract}
ABSTRAK
Cendawan tanah merupakan salah satu mikrobia tanah yang dapat bersifat menguntungkan atau merugikan bagi tanaman, sehingga berperan penting dalam bidang pertanian. Penelitian ini bertujuan untuk mengetahui kelimpahan dan karakterisasi cendawan tanah di daerah rizosfer sawi. Isolasi dan identifikasi cendawan tanah dilakukan di Laboratorum Hama dan Penyakit Fakultas Pertanian Universitas Borneo Tarakan. Cendawan tanah dikarakterisasi secara makroskopis dan mikroskopis, dan dilakukan uji patogenesitas, uji aktivitas melarutkan fosfat, uji aktivitas proteolitik dan uji hidrolisis kitin. Hasil penelitian diperoleh 34 koloni cendawan. Berdasarkan karakteristik fenotip terdapat 9 isolat cendawan dengan karakteristik yang berbeda, 4 isolat dari 9 isolat bersifat non patogen. Pada isolat cendawan yang non patogenik, diperoleh 2 genus yaitu genus Phialophora sp. dan Paecilomyces sp. Isolat cendawan non patogenik yang diperoleh ada yang memiliki aktivitas proteolitik dan hidrolisis kitin sehingga berpotensi sebagai pupuk hayati dan agens hayati.
\end{abstract}

Kata kunci: Cendawan tanah, rizosfer, karakterisasi

\section{PENDAHULUAN}

Tanaman sawi merupakan salah satu komoditas unggulan Kota Tarakan. Petani di kota Tarakan memiliki kearifan lokal yaitu dalam berbudidaya selalu menggunakan pupuk organik yaitu kotoran ayam dan pupuk limbah udang (kepala dan kulit udang). Menurut para petani dengan menggunakan pupuk tersebut kualitas sayuran mereka lebih baik, kesegaran sawi bertahan lebih lama dibandingkan dengan penggunaan pupuk kimia. Penggunaan pupuk kotoran ayam dan limbah udang akan mempengaruhi kehidupan mikroorganisme tanah di daerah rizosfer sawi.

Cendawan merupakan salah satu mikroorganisme tanah yang terdapat dalam jumlah banyak di daerah rhizosfer. Keberadaan cendawan di dalam tanah dipengaruhi oleh kandungan air tanah, kandungan bahan organik dan temperatur (Rousk et al. 2010). Hasil penelitian Lubis (2008) menunjukkan pemberian bahan organik dapat meningkatkan pertumbuhan dan aktifitas cendawan. Cendawan tanah ada yang menguntungkan dan ada yang merugikan. Golongan yang merugikan adalah yang 
menyebabkan penyakit tanaman, seperti Fusarium oxysporum. Cendawan tanah yang menguntungkan, yang memilki kemampuan menyediakan hara dan bersifat sebagai agen hayati.

Golongan cendawan yang mampu menyediakan hara salah satunya adalah cendawan pelarut fosfat, yang dapat meningkatkan ketersediaan fosfat di dalam tanah sehingga dapat diserap oleh tanaman. Beberapa cendawan dilaporkan memiliki kemampuan untuk melarutkan fosfat yang tidak larut dalam tanah antara lain dari genus Aspergillus, Penicillium, Fusarium, dan Sclerotium (Vazquez et al. 2000). Cendawan tanah ada juga yang memiliki kemampuan menghasilkan enzim protease yaitu enzim yang mampu menguraikan protein menjadi asam-asam amino. Beberapa cendawan yang menghasilkan enzim yaitu Aspergillur niger, Aspergillus, Aspergillus awamori, Mucor sp., Penicillium sp., Trichoderma dan lain-lainnya (Nygren et al. 2007).

Cendawan tanah dapat mengendalikan pathogen tanaman melalui berbagai mekanisme antara lain: melalui produksi enzim selulase, kitinase, pektinase, protease dan lipase untuk melisis dinding sel; mekanisme mikoparasitisme; mendegradasi miselium dan mekanisme antibiosis (Gomes et al. 2015). Cendawan tanah yang digunakan sebagai agen antagonis untuk mengendalikan pathogen antara lain Trichoderma harzianum untuk menekan perkembangan patogen $R$. microporus pada tanaman karet (Jayasuriya dan Thennakoon, 2007).

Pemanfaatan mikroorganisme tanah khususnya cendawan tanah sudah banyak dilakukan di bidang pertanian, lingkungan dan berbagi bidang lainnya. Potensi plasma nutfah mikroorganisme tanah masih sangat besar, oleh karena itu penelitian ini dilakukan untuk mengeksplorasi dan mengkarakterisasi cendawan tanah di rizosfer sawi dan diharapkan dapat dimanfaatkan untuk penelitian lebih lanjut.

\section{BAHAN DAN METODE}

Penelitian ini dilaksanakan di Laboratorium Hama dan Penyakit, Fakultas Pertanian Universitas Borneo Tarakan, pada bulan Juli - September 2017. Bahan yang digunakan pada penelitian ini antara lain sampel tanah, media Skim Milk Agar (SMA), media Pikovskaya's Agar (PVK), media Potato Dextrose
Agar (PDA), media kitin, $\mathrm{NaOCl}$ (Natrium Hipoklorit), benih mentimun (Cucumis sativus), Varietas Mercy F1, akuades steril, alkohol 70\%, agar-agar, plastik tahan panas dan aluminium foil.Kegiatan dalam penelitian ini terdiri dari 2 tahap yaitu: 1) pengambilan sampel tanah rizosfer tanaman sawi dan 2) isolasi dan karakterisasi cendawan.

\section{Pengambilan Sampel Tanah dan Isolasi Cendawan Tanah}

Pengambilan sampel tanah rizosfer sawi dilakukan pada kedalaman $5-10 \mathrm{~cm}$. Masingmasing sampel tanah diambil $10 \mathrm{~g}$ kemudian dimasukkan ke dalam $100 \mathrm{ml}$ akuades lalu dikocok hingga homogen. Selanjutnya dilakukan pengenceran berseri hingga mencapai kepadatan 10-5. Sebanyak $100 \mu \mathrm{l}$ suspensi dari pengenceran $10^{-1}, 10^{-3}$, dan $10^{-5}$ diratakan pada media PDA dan diinkubasi selama 3 hari (Elias et al. 2016).

Karakterisasi morfologi cendawan tanah

Pengamatan morfologi makroskopis dilakukan dengan cara mendekripsikan bentuk, ukuran, warna, elevasi, dan tepian cendawan yang tumbuh pada media PDA (Elias et al. 2016).

\section{Uji Patogenesitas}

Sebelum dilakukan uji patogenesitas, isolat cendawan ditumbuhkan pada media Potato Dextrose Agar selama 3 hari. Uji patogenesitas menggunakan benih mentimun Varietas Mercy F1 sebagai indicator. Benih mentimun disterilisasi menggunakan $0,1 \% \mathrm{NaOCl}$, kemudian direndam ke dalam akuades steril selama 3 jam. Benih mentimun yang sudah steril diletakkan di atas hifa cendawan. Benih mentimun diinkubasi selama 7 hari dan diamati gejala yang muncul. Isolat cendawan yang menyebabkan benih mentimun tidak tumbuh dan menimbulkan gejala layu, nekrotik, hawar, klorosis, atau busuk tidak digunakan pada pengujian selanjutnya (Ramdan et al. 2014).

\section{Uji Kemampuan Cendawan dalam Melarutkan Fosfat}

Aktifitas melarutkan fosfat diuji dengan menggunakan media Pikovkaya's Agar. Isolat cendawan ditumbuhkan permukaan media dan diinkubasi pada suhu ruang selama 48 jam. Isolat cendawan mampu melarutkan fosfat terlihat dengan adanya zona bening di sekitar koloni cendawan Pengujian ini bertujuan untuk mengetahui kemampuan cendawan dalam melarutkan fosfat (Mohanty et al. 2017). 


\section{Uji Aktivitas Proteolitik Cendawan}

Pengujian dilakukan menggunakan media susu skim agar pada $\mathrm{pH}$ 6,5. Isolat cendawan ditumbuhkan pada media skim agar, kemudian diinkubasi pada suhu ruang selama 48 jam. Aktifitas proteolitik diindikasikan dengan adanya zona bening disekitar koloni cendawan, Pengujian ini bertujuan untuk mengetahui kemampuan cendawan dalam memproduksi enzim protease (Vermelho et al. 1996).

\section{Uji Aktivitas Hidrolisis Kitin}

Isolat cendawan diinokulasikan ke media kitin, kemudian diinkubasikan selama 7 (tujuh) hari pada suhu ruang. Aktivitas hidrolisis kitin ditunjukkan dengan zona bening pada media kitin ((Hjort et al 2014). Uji kemampuan hidrolisis kitin yaitu untuk mengetahui potensi cendawan dalam melarutkan kitin, jika cendawan yang diuji mampu melarutkan kitin maka cendawan tersebut memiliki potensi sebagai agens pengendali hayati.

Identifikasi Cendawan

Identifikasi cendawan dilakukan berdasarkan pengamatan makroskopis koloni dan mikroskopis sel cendawan (meliputi bentuk sel, ukuran, ada tidaknya hifa atau pseudohifa, dan tipe spora. Sebagai acuan identifikasi digunakan buku kunci determinasi jamur yaitu Soil and Seed Fungi: Morphologies of Cultured Fungi and Key to Species (Watanabe 2002).

\section{HASIL DAN PEMBAHASAN}

Isolasi dan karakterisasi cendawan

Hasil isolasi cendawan daerah rhizosfer tanaman sawi (Brassica juncea L.) dengan pemberian pupuk organik kotoran ayam dan limbah udang, diperoleh 34 koloni cendawan yang tumbuh pada media PDA. Koloni cendawan yang tumbuh hanya pada tingkat pengenceran $10^{-1}$ sedangkan pada tingkat pengenceran $10^{-3}$ dan $10^{-5}$ tidak terdapat koloni cendawan yang tumbuh.

Hasil karakteristik fenotip (pengamatan makroskopis) dari 34 koloni yang tumbuh, terdapat 9 koloni yang memiliki karakteristik berbeda (Tabel 1). Bentuk koloni didominasi oleh bentuk bulat, tepian koloni didominasi oleh entire, ukuran koloni sebagian besar berukuran besar, elevasi koloni paling dominan datar sedangkan warna koloni bervariasi.

Tabel 1. Hasil karakterisasi fenotip koloni cendawan rizosfer sawi

\begin{tabular}{cccccc} 
Kode isolate & Bentuk & Warna & Ukuran & Elevasi & \multirow{2}{*}{ Tepian } \\
& & & & & \\
\hline C1 & Bulat & Putih & Besar & Datar & Entire \\
\hline C2 & Bulat & Kekuningan & Sedang & Cembung & Entire \\
\hline C3 & Bulat & Putih & Sedang & Datar & Undulate \\
\hline C4 & Bulat & Putih & Besar & Datar & Entire \\
\hline C6 & Tidak Beraturan & Kuning Kecoklatan & Besar & Datar & Undulate \\
\hline C7 & Bulat & Jinga Kekuningan & Besar & Datar & Entire \\
\hline C8 & Bulat & Putih & Besar & Cembung & Entire \\
\hline C9 & Bulat & Putih kehitaman & Besar & \multirow{2}{*}{ Datar } & \multirow{2}{*}{ Entire } \\
\hline
\end{tabular}

\section{Hasil Uji Patogenesitas}

Hasil uji patogenesitas dari 9 isolat cendawan yang diuji, menunjukkan 4 isolat cendawan bersifat non patogenik dan 6 isolat cendawan bersifat patogenik. Isolat cendawan yang non patogenik adalah $\mathrm{C} 2, \mathrm{C} 6, \mathrm{C} 7$ dan $\mathrm{C} 9$. Cendawan patogenik dapat menyebabkan benih tidak berkecambah, nekrosis pada kecambah, menghambat pertumbuhan kecambah, bahkan kematian kecambah. Hal ini disebabkan beberapa cendawan menghasilkan metabolit sekunder yang bersifat toksin bagi benih atau kecambah (Howlett 2006).

\section{Hasil Uji Kemampuan Cendawan Melarutkan Fosfat, Aktivitas Proteolitik dan Hidrolisis Kitin}

Pada penelitian ini, cendawan yang non patogenik diuji kemampuannya dalam melarutkan fosfat, menghasilkan enzim protease dan menghidrolisis kitin. Hasil pengujian tersebut ditampilkan dalam Tabel 2. Hasil uji melarutkan 
fosfat menunjukkan 4 isolat yang diuji tidak memiliki kemampuan melarutkan fosfat. Pada pengujian aktivitas proteolitik diperoleh 2 isolat cendawan yang mampu menghasilkan enzim protease yaitu isolate $\mathrm{C} 2$ dan $\mathrm{C} 7$. Isolat cendawan C7 juga memiliki kemampuan menghidrolisis kitin.

Tabel 2. Hasil uji aktivitas pelarut fosfat, aktivitas proteolitik dan hidrolisis kitin

\begin{tabular}{|c|c|c|c|}
\hline Kode isolat & Aktivitas pelarut fosfat & Aktivitas proteolitik & Hidrolisis kitin \\
\hline $\mathrm{C} 2$ & - & + & - \\
\hline C6 & - & - & - \\
\hline C7 & - & + & + \\
\hline C9 & - & - & - \\
\hline
\end{tabular}

Keterangan: + = memiliki kemampuan; - = tidak memiliki kemampuan

Kemampuan melarutkan fosfat suatu cendawan disebabkan oleh aktivitas asam organik yang dihasilkan cendawan. Menurut Pradhan dan Sukla (2006) setiap cendawan pelarut fosfat menghasilkan jenis dan jumlah asam organik yang berbeda serta satu jenis cendawan pelarut fosfat menghasilkan lebih dari satu jenis asam organik. Asam-asam organik ini akan membentuk kompleks stabil dengan kation $\mathrm{Al}, \mathrm{Fe}$, sehingga fosfat akan terbebas dari ikatannya dan mudah diserap oleh akar. Berdasarkan hasil penelitian Fatmala et al. (2015) diketahui beberapa genus cendawan yang mampu melarutkan fosfat diantaranya Penicillium sp., Aspergillus sp., dan Trichoderma sp. Pada penelitian ini tidak diperoleh isolate cendawan yang mampu melarutkan fosfat.

Aktivitas proteolitik berhubungan dengan dekomposisi bahan organik. Isolate cendawan yang memiliki aktivitas proteolitik berarti cendawan tersebut mampu menghasilkan enzim protease yang dapat memutuskan ikatan peptida suatu protein (Susanti 2005) pada proses dekomposisi bahan organik. Hasil pemecahan protein berupa senyawa sederhana atau senyawa anorganik (unsur hara) yang dbutuhkan tanaman. Isolat C2 dan C7 memiliki aktivitas proteolitik, sehingga berpotensi untuk digunakan sebagai pupuk hayati.

Cendawan yang memiliki kemampuan menghidrolisis kitin artinya cendawan tersebut mampu menghasilkan enzim kitinase, yaitu enzim yang dapat mengkatalisis reaksi degradasi kitin (Yati 2015). Kitin merupakan biopolimer yang terdapat pada dinding sel nematode, cangkang Crustacea dan serangga. Hasil penelitian ini menunjukkan isolate $\mathrm{C} 7$ selain memiliki aktivitas proteolitik juga mampu menghidrolisis kitin, sehingga isolate C7 juga berpotensi sebagai agens hayati.

\section{Hasil Identifikasi Cendawan Tanah}

Berdasarkan pengamatan makroskopik dan mikroskopik dan mengacu pada buku kunci determinasi jamur (Watanabe 2002) maka isolate C2 dan C9 masuk dalam genus Phialophora sp. Isolat C6 dan C7 termasuk dalam genus Paecilomyces sp. Hasil pengamatan mikroskopik sel cendawan ditampilkan pada Tabel 3 dan Gambar 1 dan 2

Tabel 3. Hasil pengamatan mikroskopik sel cendawan

\begin{tabular}{clcc}
\hline Kode Isolat & \multicolumn{1}{c}{ Bentuk Sel } & Tipe Hifa & Genus \\
\hline C2 & Semi bulat & Tidak bersekat & Phialophora sp \\
\hline C6 & Bulat & Bersekat & Paecilomyces sp \\
\hline C7 & Bulat & Bersekat & Paecilomyces sp \\
\hline C9 & Semi bulat & Bersekat & Phialophora sp \\
\hline
\end{tabular}




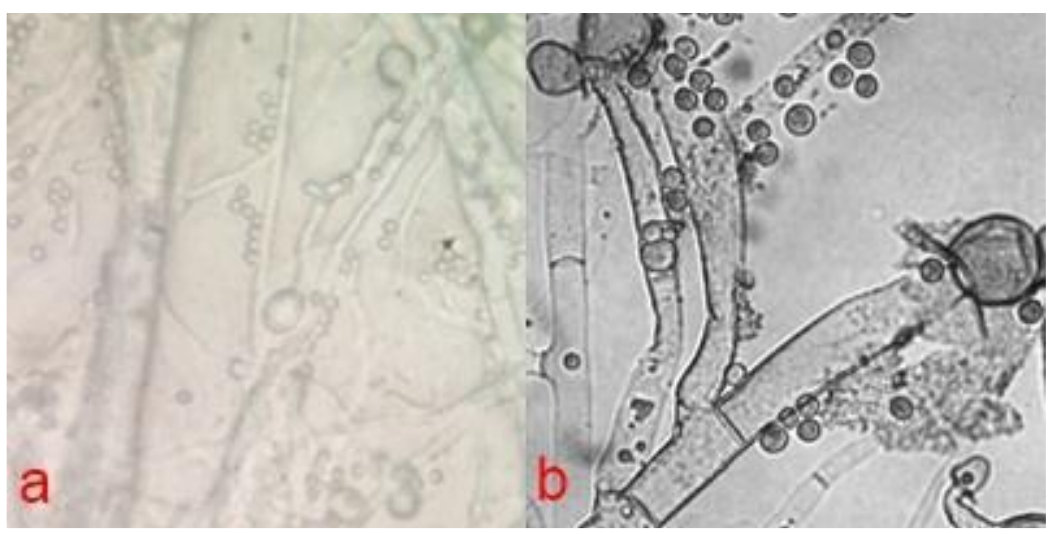

Gambar 1. a. Hasil pengamatan mikroskopik isolate C2; b. Bentuk sel dan tipe hifa genus Phialophora sp pada buku kunci determinasi fungi (Watanabe 2002)

Genus Phialophora sp. memiliki bentuk sel semi bulat/bulat dengan ciri hifa tidak bersekat/bersekat, membentuk konidium dengan tangkai disebut konidiosfor. Cendawan spesies Phialophora merupakan cendawan tanah yang juga sering ditemui bersifat sebagai endofit. Cendawan ini diketahui mampu memproduksi berbagai senyawa antimikroba. Phialophora juga dilaporkan mampu meningkatkan pertumbuhan beberapa jenis tanaman, Phialophora sering ditemukan pada sisa bahan organik yang telah dikomposkan, pupuk kandang, dan vermikompos. Sampai saat ini belum banyak laporan mengenai cendawan ini dan peranannya dalam bidang pertanian (Mengistu et al. 1991).

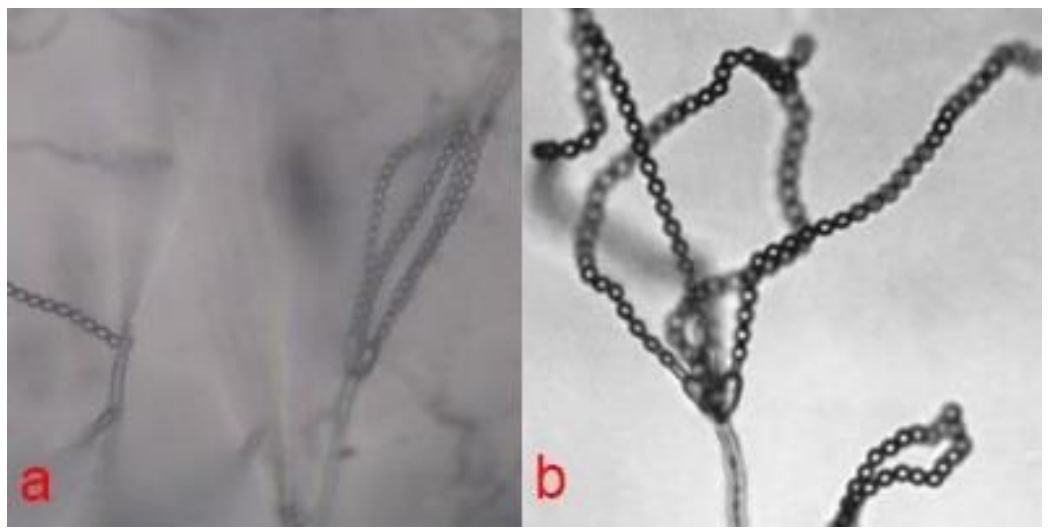

Gambar 1. a. Hasil pengamatan mikroskopik isolate C6; b. Bentuk sel dan tipe hifa genus Paecilomyces sp pada buku kunci determinasi fungi (Watanabe 2002)

Paecilomyces sp. termasuk kelas ascomycota dari ordo Eurotiales. Genus Paecilomyces sp. Menunjukkan rantai konidiosfor bersel tunggal, konidia berbentuk seperti rantai dengan phialides bengkak di pangkalan secara tertahap merunging, dan membentuk seperti kuas, memiliki hifa bersekat (Watanabe 2002). Genus Paecilomyces sp. diketahui dapat menghasilkan kitinase, dan beberapa telah digunakan sebagai agens biokontrol untuk mengendalikan proses destruksi nematoda serta dapat menjadi entomopatogenik, mikoparasitik, saprofitik sebagai nematofagus (Kiewnick dan Sikora 2006).

\section{KESIMPULAN}

Hasil isolasi dan karakterisasi cendawan dari rizosfer sawi diperoleh 34 koloni cendawan. Berdasarkan karakteristik fenotip terdapat 9 isolat cendawan dengan karakteristik yang berbeda, 4 isolat dari 9 isolat bersifat non patogen. Pada isolat cendawan yang non patogenik, diperoleh 2 genus yaitu genus Phialophora sp. dan Paecilomyces sp. Isolat cendawan non patogenik yang diperoleh ada yang memiliki aktivitas proteolitik dan hidrolisis kitin sehingga berpotensi sebagai pupuk hayati dan agens hayati. 


\section{UCAPAN TERIMAKASIH}

Terimakasih disampaikan kepada Ankardiansyah Pandu Pradana, SP., MSc dan Nurjannah S.Si, M.Sc atas bantuannya sehingga penelitian ini dapat terlaksana dengan baik.

\section{DAFTAR PUSTAKA}

Elias F, Woyessa D, Muleta D. 2016. Phosphate solubilization potential of rhizosphere fungi isolated from plants in Jimma Zone, Southwest Ethiopia. International Journal of Microbiology 2016: 1-11.

Fatmala V, Sembiring M, Jamilah J. 2015. Eksplorasi dan potensi jamur pelarut fosfat pada andisol terkena dampak erupsi Gunung Sinabung dengan beberapa ketebalan abu di Kecamatan Naman Teran Kabupaten Karo. Agroteknologi 3 (3): 1164-1168.

Gomes EV, do Nascimento Costa M, De Paula RG, De Azevedo RR, Da Silva FL, Noronha EF, Ulhoa CJ, Monteiro VN, Cardoza RE, Gutierrez S. 2015. The cerato-platanin protein Epl-1 from Trichoderma harzianum is involved in mycoparasitism, plant resistance induction and self cell wall protection. Scientific Reports 5: $1-11$.

Hjort K, Presti I, Elväng A, Marinelli F, Sjöling S. 2014. Bacterial chitinase with phytopathogen control capacity from suppressive soil revealed by functional metagenomics. Applied microbiology and biotechnology 98(6):28192828.

Howlett BJ. 2006. Secondary metabolite toxins and nutrition of plant pathogenic fungi. Current Opinion in Plant Biology 9 (4): 371-375.

Jayasuriya, K. E. and Thennakoon B. I. 2007. Biological control of Rigidoporus microporus, The cause of white root disease in rubber. Cey. J. Sci. (Bio. Sci.) 36 (1): 9-16.

Kiewnick S, Sikora R. 2006. Biological control of the root-knot nematode Meloidogyne incognita by Paecilomyces lilacinus strain 251. Biological Control 38 (2): 179-187.

Lubis S. 2008. Dinamika Populasi Jamur pada Tanah Ultisol Akibat Pemberian Berbagai Bahan Organik Limbah Perkebunan. [Skripsi]. Universitas Sumatera Utara, Medan. [Indonesia]
Mengistu A, Tachibana H, Grau C. 1991. Selective medium for isolation and enumeration of Phialophora gregata from soybean straw and soil. Plant Disease 75 (2): 196-199.

Mohanty S, Ghosh S, Nayak S, Das A. 2017. Isolation, identification and screening of manganese solubilizing fungi from low-grade manganese or deposits. Geomicrobiology Journal 34 (4): 309-316.

Nygren CM, Edqvist J, Elfstrand M, Heller G, Taylor AF. 2007. Detection of extracellular protease activity in different species and genera of ectomycorrhizal fungi. Mycorrhiza 17 (3) :241-248.

Pradhan N, Sukla L. 2006. Solubilization of inorganic phosphates by fungi isolated from agriculture soil. African Journal of Biotechnology 5 (10): 850-854.

Ramdan EP, Widodo W, Tondok ET, Wiyono S, Hidayat SH. 2014. Cendawan endofit nonpatogen asal tanaman cabai dan potensinya sebagai agens pemacu pertumbuhan. Jurnal Fitopatologi Indonesia 9 (5): 139-144.

Rousk J, Baath E, Brookes PC, Lauber CL, Lozupone C, Caporaso JG, Knight R, Fierer N. 2010. Soil bacterial and fungal communities across a $\mathrm{pH}$ gradient in an arable soil. The ISME Journal 4 (10): 1340-1350.

Vazquez P, Holguin G, Puente M, Lopez-Cortes A, Bashan Y. 2000. Phosphatesolubilizing microorganisms associated with the rhizosphere of mangroves in a semiarid coastal lagoon. Biology and Fertility of Soils 30 (5-6): 460-468.

Vermelho AB, Meirelles MNL, Lopes A, Petinate SDG, Chaia AA, Branquinha MH. 1996. Detection of extracellular proteases from microorganisms on agar plates. Memorias do Instituto Oswaldo Cruz 91 (6): 755-760.

Watanabe, T. 2002. Pictorial Atlas of Soil and Seed Fungi Morphologies of Cultured Fungi and Key to Species. Second Edition. CRC Press LLC. [USA].

Yati SS. 2015. Karakterisasi Enzim Kitinase dan Identifikasi Isolat Aktinomisetes KRC 21.D Berasal dari Kebun Raya Cibodas. Biodiversitas 1 (5): 1156-1161. 